\title{
BRIEF
}

\section{Evaluation of A Fourth-Year Student Pharmacist Research Process in A Community Teaching Health System}

\author{
Jennifer Kim, PharmD, ${ }^{\mathrm{a}, \mathrm{b}, \mathrm{c}}$ Savannah K McPherson, ${ }^{\mathrm{a}}$ Peter Koval, PharmD, ${ }^{\mathrm{a}, \mathrm{b}, \mathrm{c}}$ Megan Tran, ${ }^{\mathrm{a}}$ Hannah Feinman ${ }^{\mathrm{a}}$ \\ ${ }^{a}$ University of North Carolina, Eshelman School of Pharmacy, Chapel Hill, North Carolina \\ ${ }^{\mathrm{b}}$ Area Health Education Center, Greensboro, North Carolina \\ ${ }^{\mathrm{c}}$ Cone Health, Greensboro, North Carolina
}

Corresponding Author: Jennifer Kim, University of North Carolina, Eshelman School of Pharmacy, 301 Pharmacy Ln, Chapel Hill, NC 27599. Tel: 336-832-7885. Email: jen.kim@conehealth.com

Submitted October 23, 2020; accepted June 16, 2021; ePublished June 2021

\begin{abstract}
Objective. Doctor of pharmacy programs are encouraged to incorporate research training in their curricula, but literature is lacking describing health system student research support. The purpose of this study is to evaluate a process supporting fourth-year student pharmacist research in a health system affiliated with a school of pharmacy.

Methods. In 2017, clinical non-tenure track faculty transitioned from facilitating a fourth-year research elective to implementing a new student research process which matches students to research preceptors at the beginning of the academic year and provides training and resources throughout the year. This institutional review board approved pre-post study evaluated student pharmacist research participation, dissemination, and position placement at the time of graduation, comparing 3 years before to 3 years after new process implementation.

Results. Thirty-three fourth-year students assigned to the health system graduated during 2015-2017, and 31 graduated 2018-2020. The percent of students who completed research projects increased significantly $(48.5 \%$ vs $87.1 \%, p=.0013)$, the number of projects increased significantly (18 vs 35, $=.0047)$, presentations increased significantly ( 29 vs 63 , $p=.0001$ ), and publications increased numerically ( $9 \mathrm{vs} 16, p=.0699)$. Notably, the percent of research students who pursued postgraduate training increased $(68.8 \%$ vs $96.3 \%)$, as well as the rate of placement into training programs $(81.8 \%$ vs $92.3 \%$ ); for non-research students, the percent who pursued training also increased (17.6\% vs $75 \%$ ), but the rate of placement remained the same $(66.7 \%)$.

Conclusion. The new fourth-year pharmacy student research process supported increased research productivity. Keywords: student research, student pharmacist, advanced practice experience, scholarly activity, research preceptor
\end{abstract}

\section{INTRODUCTION}

Research participation improves high-level skills such as problem-solving, critical thinking, communication, leadership, collaboration and innovation. ${ }^{1}$ These abilities are assets to pharmacy, as research can demonstrate positive patient outcomes resulting from pharmacist integration on the health care team, support career advancement, and advance the profession as a whole. ${ }^{1}$ Positive associations have been identified with student pharmacist research participation, including increased likelihood of postgraduate and specialty training, continuation to faculty appointment, and lifetime publication rate. ${ }^{1}$

Benefits of scholarship on the profession are valued by pharmacy organizations such that doctor of pharmacy programs are encouraged to incorporate research training in their curricula. ${ }^{1-3}$ Pharmacy schools utilize lectures, elective and required courses, and dual-degree programs. However, most colleges of pharmacy do not require student hands-on research participation. Faculty face ever changing workloads and students experience time constraints juggling academic rigor with work and leadership roles to remain competitive as future applicants to postgraduate opportunities. Therefore, it is imperative to examine strategies for fostering student pharmacist research. A retrospective cohort study of student pharmacists found that out of 1229 graduates, research participation, with a majority of students enrolled in a research course for credit, and scholarly productivity increased significantly from 2009-2015 compared to 2002-2008, owing to students beginning feasible projects early in the professional program, dedicated mentorship of motivated non-tenure track practice faculty, and group project opportunities. ${ }^{1}$

To date, there is limited insight describing longitudinal student pharmacist research programs. A pre-post study $(\mathrm{N}=65)$ of a longitudinal, 12-month research experience (L-APPE) witnessed a 6-fold increase in the number of national poster presentations (from 6 to 36, $p<.01$ ) during the 5 years after L-APPE implementation compared to 5 years prior, with a significant increase in projects benefiting practice $(57.1 \%$ vs $83.3 \%, p=.03) .{ }^{4}$ In another study of an APPE, which 
was a capstone in research, of 80 students who participated, all presented posters, 2 projects were published in peerreviewed journals, and the perception of the experience was positive, allowing students to apply findings to real-world scenarios. ${ }^{5}$ In a large academic medical center, a research program was implemented for student pharmacists in their first, second or third year. ${ }^{6}$ Compared to 2009 , the number of student research participants per year was substantially higher in 2013 (2 and 16, respectively), and the number of posters and publications increased from 1 to 19 and 0 to 2, respectively.

More diverse insight into strategies adopted by health systems to support student research may be helpful for experiential rotation sites with varying resources or affiliations. The objective of this study is to describe a new fourthyear student pharmacist research process, implemented in a moderately-sized health system affiliated with a university college of pharmacy, with outcomes including student research participation, dissemination, and postgraduate training or job placement at the time of graduation.

\section{METHODS}

From 2014 to 2017, pharmacy educators from a community teaching health system facilitated a four-credit-hour research elective for fourth-year advanced pharmacy practice experience (APPE) student pharmacists who were assigned to the health system from an affiliated university. Drug literature evaluation and statistics courses were pre-requisites for this course, in which didactic sessions and resources covering research topics were provided throughout the year. Each student was expected to identify a mentor, complete a longitudinal research project including Institutional Review Board (IRB) approval, present a poster at a pharmacy conference, and provide a 10-minute podium presentation to the health system. Assistance was provided to students as needed throughout the year.

In 2017, the research elective was discontinued and a clinical/non-tenure track faculty implemented a new process supporting fourth-year APPE student research. No pre-requisites were required for students to participate in the new process, which did not provide course credit but proactively matched students with mentors who had mutual research interests. In March each year, the faculty, who also served as chair of the pharmacy research committee (PRC), requested preceptors to submit student research project interests. Preceptors stemmed from diverse areas ranging from administration, community pharmacy, and generalist clinical practice (inpatient and primary care), to inpatient and outpatient specialties (eg, oncology, cardiology, infectious diseases, pediatrics). The clinical faculty received 10 to 15 preceptor submissions each year, and each preceptor mentored or co-mentored 1 student project per year. The PRC reviewed preceptor project ideas and provided constructive feedback to each preceptor in an effort to optimize feasibility of each project. Examples of feedback included considering the need for committee approval (ie, Pharmacy \& Therapeutics), informed consent, order sets, or data reports for process implementation, encouraging practical study designs, incorporating diverse outcomes (ie, quality, financial), reviewing whether the implementation timeline fits the academic calendar, and developing a process for data collection by the student.

In May, the faculty requested students to share their top three research interest areas, then matched students, starting with their first choice, to preceptors who submitted interests in March. The faculty, along with IRB coordinators, provided students 1 hour of research training (Figure 1), required students to complete a Collaborative Institutional Training Initiative course, and expected students to sign a research agreement with their mentor which described responsibilities and estimated hours anticipated to dedicate to the research process.

Throughout the year, the faculty provided information about resources (eg, statistician, data analytics, information technology) and education available within the health system (eg, live education provided by preceptors, electronic medical record report writing training, resident research discussions), notification of local, state, and national poster and platform presentations, and workshops covering abstract development, poster presentations, and manuscript writing. The faculty announced these opportunities via email or during in-person or virtual student meetings, and emailed the students as a group at least monthly to offer help with research progress. The faculty also encouraged students to complete a poster presentation and a year-end 10-minute platform presentation to the health system.

This study was an Institutional Review Board (IRB) approved pre-post comparison 3 years before vs 3 years after implementation of the new student research process. The primary outcome is the percent of fourth-year student pharmacists assigned to the health system who completed research projects. Secondary outcomes include posters, podium presentations, publications, and postgraduate training or job placement at the time of graduation.

At the end of each academic year, the faculty sent an email to students inquiring about scholarly activity and position placement. Data for posters, publications, and presentations were collected using student self-report, Scopus ${ }^{\circledR}$ and MEDLINE (PubMed). Position placement at graduation was collected by student self-report. Data was analyzed with Fisher's exact tests, paired t-tests and descriptive statistics using NCSS (Kaysville, UT 2015). ${ }^{7}$

\section{RESULTS}


Thirty-three fourth-year students were assigned to the health system for the classes graduating 2015-2017, and a total of 31 students were assigned for the classes graduating 2018-2020 (Table 1). The percent of students participating in research within the health system increased from $48.5 \%$ in $2015-2017$ to $87.1 \%$ in $2018-2020$ ( $p=.0013$ ), and the number of research projects increased from 18 to 35 ( $p=.0047)$. Research dissemination increased significantly from a mean of 1.2 per student to 2.5 per student ( $p=.0002)$, driven by a significant increase in presentations from 29 to 63 ( $p=.0001)$, while publications increased numerically from 9 to 16 ( $p=.0699$, not statistically significant).

Of 43 total students who completed research projects, the percentage who pursued training (residency or fellowship) increased from $68.8 \%$ to $96.3 \%$ (Table 2). Of these, 38 total students pursued training, and the rate of those who placed into a training program increased from $81.8 \%$ to $92.3 \%$. Of 21 students who did not complete research projects, the percentage who pursued training also increased from 3 years before to 3 years after implementation $(17.6 \%$ vs $75 \%)$, but the placement rate remained the same during both time periods $(66.7 \%)$.

\section{DISCUSSION}

Our new student research process upheld a significant increase in productivity. Compared to the previous research process, which began in May each year and placed the onus on students, the new process engaged preceptors in March and fleshed out project ideas prior to making them available for students. By May, students were matched to preceptors with projects which were potentially more feasible than in years past. We also did not require pre-requisite courses. We communicated resources throughout the year, which may have encouraged students to disseminate findings. This new approach is similar in ideology to the flipped residency research model, which was found to align better with resident experiences and abilities. ${ }^{9}$ Since the time of our study, we have implemented a flipped model for students to be matched to preceptors soon after they are assigned to our health system (during the fall of third year), and encourage preceptors to pursue IRB approval before May. We also support research for second- and third-year student pharmacists assigned to the health system. Early exposure to research, as soon as the first year, with increasing involvement to the goal of dissemination by fourth year, may improve the experience and broaden opportunities. ${ }^{9}$

The publication by Michalets et al. described a similar study of a longitudinal research course (L-APPE) compared to co-curricular student-driven research, highlighting the importance of structured support in research productivity. ${ }^{4}$ Comparatively, our health system is smaller with fewer clinical faculty, is not a satellite campus for the affiliated school of pharmacy, our implementation phase occurred during a different time period, and we did not provide course credit. We witnessed an increase in research participation (48.5\% pre-implementation vs $87.1 \%$ postimplementation) compared to the L-APPE study (43.4\% pre-implementation vs $40.2 \%$ post-implementation). This may have been influenced by increased professional competitiveness. Students pursuing postgraduate training may be instinctively more likely to participate in research. We did not evaluate motivation to participate, but we did observe an increase in the pursuit of training programs overall, for students who participated in research (from 68.8\% to 96.3\%) and for students who did not participate in research (from $17.6 \%$ to $75 \%$ ). It is unclear whether our health system could have supported the influx of student researchers without the new process.

Other limitations of our study include small sample size, retrospective study design as opposed to prospective, and confounding factors (eg, increased competition in the profession, diverse student career interests, high academic and leadership performance influencing position placement). Job placement data was not recorded in 2015 but was in the following years. We also did not differentiate between local or national presentations, research projects conducted outside of the health system, or impact on practice. Recent graduates may still be pursuing manuscript publications which could underestimate their scholarly activities. Further, position placement after graduation and long-term career outcomes were not tracked.

To our knowledge, ours is the first study of a longitudinal student pharmacist research process which observed career placement. Although a causal relationship cannot be identified due to the limitations discussed, student pharmacists who participated in research showed a numerical increase in placement rates into training programs (81.8\% vs $92.3 \%)$, whereas the placement rate did not change for students who did not participate in research $(66.7 \%$ vs $66.7 \%)$. Notably, our postgraduate placement rate prior to implementation of the new research process was $81.8 \%$, which was similar to the affiliated university match rate $(81.6 \%) .{ }^{10}$ During the 3 years after implementation of the new research process, our postgraduate placement rate of $92.6 \%$ exceeded the university match rate $(84.9 \%)$. This relationship warrants further investigation.

This study can be generalized by exploring strategies and relationships supporting student pharmacist research, including how they can best sustain and expand research opportunities, and their associated outcomes. Examples of outcomes to be explored include research participation and motivators, impact on practice, short-term and long-term career impact and scholarly activity, and perceptions. Different perspectives may also be considered, including layered learners, preceptors, administrators, research teams, and interprofessional members. Institutions differ in resources and 
data available, but further research can improve our understanding of how we can best support student pharmacist research training and its ripple effect on the profession.

\section{CONCLUSION}

The new fourth-year student pharmacist research process supported a higher number of student research participants, research projects, and presentations.

\section{REFERENCES}

1. Osborne KW, Woods KM, Maxwell WD, McGee K, Bookstaver PB. Outcomes of student-driven, faculty-mentored research and impact on postgraduate training and career selection. Am J Pharm Educ. 2018;82(4):6246.

2. Accreditation Council for Pharmacy Education. Accreditation standards and guidelines for the professional program in pharmacy leading to the doctor of pharmacy degree. https://www.acpe-accredit.org/pharmd-program-accreditation/. Accessed September 24, 2020.

3. Lee MW, Clay PG, Kennedy WK et al. The essential research curriculum for doctor of pharmacy degree programs. Pharmacotherapy. 2010;30:966.

4. Michalets EL, Williams C, Park I. Ten year experience with student pharmacist research within a health system and education center. Curr Pharm Teach Learn. 2018;10(3):316-324.

5. Wuller CA. A capstone advanced pharmacy practice experience in research. Am J Pharm Educ. 2010;74(10):180.

6. McLaughlin MM, Skoglund E, Bergman S, Scheetz MH. Development of a pharmacy student research program at a large academic medical center. Am J Health Syst Pharm. 2015;72(21):1885-1889.

7. NCSS 10 Statistical Software (2015). NCSS, LLC. Kaysville, Utah, USA, ncss.com/software/ncss.

8. Morbitzer KA, Rao KV, Rhoney DH, Pappas AL, Durr EA, Sultan SM, Eckel SF, Savage SW, Daniels BR, Pinelli NR. Implementation of the flipped residency research model to enhance residency research training. Am J Health Syst Pharm. 2019;76(9):608-612.

9. McClendon KS, Bell AM, Ellis A, et al. Pathways to improve student pharmacists' experience in research. Am J Pharm Educ. 2015;79(4):58.

10. American Society of Health-System Pharmacists. Match statistics. https://natmatch.com/ashprmp/stats.html. Accessed April 16, 2021. 
Table 1. Fourth-year student pharmacist research involvement and resulting scholarly activities

\begin{tabular}{|c|c|c|c|c|c|c|c|c|c|}
\hline Graduation year & 2015 & 2016 & 2017 & $\begin{array}{l}2015- \\
2017\end{array}$ & 2018 & 2019 & 2020 & $\begin{array}{l}2018- \\
2020\end{array}$ & $\begin{array}{c}\mathbf{P} \\
\text { value }^{\mathrm{a}}\end{array}$ \\
\hline $\begin{array}{l}\text { Students assigned to health system, } \\
\text { n }\end{array}$ & 10 & 12 & 11 & 33 & 11 & 10 & 10 & 31 & \\
\hline $\begin{array}{l}\text { Students who participated } \\
\text { in research, } n(\%)\end{array}$ & $5(50)$ & $6(50)$ & $\begin{array}{c}5 \\
(45.5)\end{array}$ & $\begin{array}{c}16 \\
(48.5)\end{array}$ & $\begin{array}{c}10 \\
(90.9)\end{array}$ & $\begin{array}{c}7 \\
(70.0)\end{array}$ & $\begin{array}{c}10 \\
(100)\end{array}$ & $\begin{array}{c}27 \\
(87.1)\end{array}$ & \multirow[b]{2}{*}{0.0013} \\
\hline $\begin{array}{l}\text { Students who did not } \\
\text { participate in research, } n \\
(\%)\end{array}$ & $\begin{array}{c}5 \\
(50)\end{array}$ & $6(50)$ & $\begin{array}{c}6 \\
(54.5)\end{array}$ & $\begin{array}{c}17 \\
(51.5)\end{array}$ & $\begin{array}{c}1 \\
(9.1)\end{array}$ & $3(30)$ & $0(0)$ & $4(2.9)$ & \\
\hline $\begin{array}{l}\text { Number of projects per student, } \\
\text { mean (SD) }\end{array}$ & $\begin{array}{c}0.7 \\
(0.9)\end{array}$ & $\begin{array}{c}0.5 \\
(0.5)\end{array}$ & $\begin{array}{c}0.5 \\
(0.5)\end{array}$ & $\begin{array}{c}0.5 \\
(0.7)\end{array}$ & $\begin{array}{c}0.9 \\
(0.3)\end{array}$ & $\begin{array}{c}0.7 \\
(0.5)\end{array}$ & $\begin{array}{c}1.8 \\
(1.0)\end{array}$ & $\begin{array}{c}1.1 \\
(0.8)\end{array}$ & 0.0047 \\
\hline $\begin{array}{l}\text { Dissemination per student, mean } \\
\text { (SD) }\end{array}$ & $\begin{array}{c}1.3 \\
(1.4)\end{array}$ & $\begin{array}{c}1.2 \\
(1.3)\end{array}$ & $\begin{array}{c}1.1 \\
(1.4)\end{array}$ & $\begin{array}{c}1.2 \\
(1.3)\end{array}$ & $\begin{array}{l}2.7 \\
(0.9)\end{array}$ & $\begin{array}{c}1.8 \\
(1.4)\end{array}$ & $\begin{array}{c}3.4 \\
(2.0)\end{array}$ & $\begin{array}{c}2.5 \\
(1.6)\end{array}$ & 0.0002 \\
\hline Presentations, $\mathbf{n}(\%)^{\mathrm{b}}$ & $\begin{array}{c}10 \\
(76.9)\end{array}$ & $\begin{array}{c}12 \\
(85.7)\end{array}$ & $\begin{array}{c}7 \\
(63.6) \\
\end{array}$ & $\begin{array}{c}29 \\
(76.3)\end{array}$ & $\begin{array}{c}20 \\
(74.1)\end{array}$ & $\begin{array}{c}17 \\
(94.4)\end{array}$ & $\begin{array}{c}26 \\
(76.5)\end{array}$ & $\begin{array}{c}63 \\
(79.7) \\
\end{array}$ & 0.0001 \\
\hline $\begin{array}{l}\text { Poster } \\
\text { presentations, n } \\
(\%)\end{array}$ & $5(50)$ & $6(50)$ & $\begin{array}{c}3 \\
(42.9)\end{array}$ & $\begin{array}{c}14 \\
(48.3)\end{array}$ & $\begin{array}{c}11 \\
(55)\end{array}$ & $\begin{array}{c}9 \\
(52.9)\end{array}$ & $\begin{array}{c}17 \\
(65.4)\end{array}$ & $\begin{array}{c}37 \\
(58.7)\end{array}$ & 0.0001 \\
\hline $\begin{array}{l}\text { Podium } \\
\text { presentations, n } \\
(\%)\end{array}$ & $5(50)$ & $6(50)$ & $\begin{array}{c}4 \\
(57.1)\end{array}$ & $\begin{array}{c}15 \\
(51.7)\end{array}$ & $9(45)$ & $8(47)$ & $\begin{array}{c}9 \\
(34.6)\end{array}$ & $\begin{array}{c}24 \\
(41.3)\end{array}$ & 0.0016 \\
\hline Publications, n $(\%)^{\mathrm{b}}$ & $\begin{array}{c}3 \\
(23.1)\end{array}$ & $\begin{array}{c}2 \\
(14.3)\end{array}$ & $\begin{array}{c}4 \\
(36.4)\end{array}$ & $9(23.6)$ & $\begin{array}{c}7 \\
(25.9)\end{array}$ & $\begin{array}{c}1 \\
(5.6)\end{array}$ & $\begin{array}{c}8 \\
(23.5)\end{array}$ & $\begin{array}{c}16 \\
(20.3)\end{array}$ & 0.0699 \\
\hline $\begin{array}{l}\text { Peer-reviewed, } n \\
(\%)\end{array}$ & $\begin{array}{c}3 \\
(100) \\
\end{array}$ & $\begin{array}{c}2 \\
(100) \\
\end{array}$ & $2(50)$ & $7(77.8)$ & $\begin{array}{c}6 \\
(85.7) \\
\end{array}$ & $\begin{array}{c}1 \\
(100) \\
\end{array}$ & $4(50)$ & $\begin{array}{c}11 \\
(68.8) \\
\end{array}$ & 0.2547 \\
\hline $\begin{array}{l}\text { Not peer-reviewed, } \\
\text { n }(\%)\end{array}$ & $0(0)$ & $0(0)$ & $2(50)$ & $2(22.2)$ & $\begin{array}{c}1 \\
(14.3)\end{array}$ & $0(0)$ & $4(50)$ & $5(31.2)$ & 0.2636 \\
\hline
\end{tabular}

a2015-2017 compared to 2018-2020

benominator includes presentations + publications 
Table 2. Fourth-year student pharmacist position placement at time of graduation

\begin{tabular}{|c|c|c|c|c|c|c|c|c|c|}
\hline Graduation year & 2015 & 2016 & 2017 & $\begin{array}{l}2015- \\
2017\end{array}$ & 2018 & 2019 & 2020 & $\begin{array}{l}2018- \\
2020\end{array}$ & Total \\
\hline $\begin{array}{l}\text { Students who participated in research, } \\
\text { n }(\%)\end{array}$ & $\begin{array}{c}5 \\
(50)\end{array}$ & $6(50)$ & $\begin{array}{c}5 \\
(45.5)\end{array}$ & $\begin{array}{c}16 \\
(48.5)\end{array}$ & $\begin{array}{c}10 \\
(90.9)\end{array}$ & $\begin{array}{c}7 \\
(70.0)\end{array}$ & $\begin{array}{c}10 \\
(100)\end{array}$ & $\begin{array}{c}27 \\
(87.1)\end{array}$ & $\begin{array}{c}43 \\
(67.2)\end{array}$ \\
\hline $\begin{array}{l}\text { Placement of student research } \\
\text { participants, } \mathbf{n}(\%)\end{array}$ & NR & $\begin{array}{c}6 \\
(100)\end{array}$ & $3(60)$ & $\begin{array}{c}11 \\
(\mathrm{NA})\end{array}$ & $8(80)$ & $\begin{array}{c}7 \\
(100)\end{array}$ & $\begin{array}{c}10 \\
(100)\end{array}$ & $\begin{array}{c}25 \\
(92.6)\end{array}$ & $\begin{array}{c}36 \\
\text { (NA) }\end{array}$ \\
\hline $\begin{array}{r}\text { Students who pursued training, } \\
\mathrm{n}(\%)\end{array}$ & $\begin{array}{c}2 \\
(40) \\
\end{array}$ & $\begin{array}{c}5 \\
(83.3) \\
\end{array}$ & $4(80)$ & $\begin{array}{c}11 \\
(68.8) \\
\end{array}$ & $9(90)$ & $\begin{array}{c}7 \\
(100) \\
\end{array}$ & $\begin{array}{c}10 \\
(100) \\
\end{array}$ & $\begin{array}{c}26 \\
(96.3) \\
\end{array}$ & $\begin{array}{c}38 \\
(88.4) \\
\end{array}$ \\
\hline $\begin{array}{r}\text { Students who placed into } \\
\text { training, n }(\%)\end{array}$ & $\begin{array}{c}2 \\
(100) \\
\end{array}$ & $\begin{array}{c}5 \\
(100) \\
\end{array}$ & $2(50)$ & $\begin{array}{c}9 \\
(81.8) \\
\end{array}$ & $\begin{array}{c}7 \\
(77.8) \\
\end{array}$ & $\begin{array}{c}7 \\
(100) \\
\end{array}$ & $\begin{array}{c}10 \\
(100) \\
\end{array}$ & $\begin{array}{c}25 \\
(92.3) \\
\end{array}$ & $\begin{array}{c}34 \\
(89.4) \\
\end{array}$ \\
\hline $\begin{array}{r}\text { Students who pursued a job, } \mathbf{n} \\
(\%)\end{array}$ & NR & $\begin{array}{c}1 \\
(16.7) \\
\end{array}$ & $1(20)$ & 2 (NA) & $1(10)$ & $0(0)$ & $0(0)$ & $1(3.7)$ & $\begin{array}{c}2 \\
(\mathrm{NA}) \\
\end{array}$ \\
\hline $\begin{array}{r}\text { Student who placed into a job, } \\
\text { n (\%) }\end{array}$ & NR & $\begin{array}{c}1 \\
(100)\end{array}$ & $\begin{array}{c}1 \\
(100) \\
\end{array}$ & 2 (NA) & $\begin{array}{c}1 \\
(100)\end{array}$ & NA & NA & $\begin{array}{c}1 \\
(100)\end{array}$ & $\begin{array}{c}2 \\
(\mathrm{NA}) \\
\end{array}$ \\
\hline $\begin{array}{l}\text { Students who did not participate in } \\
\text { research, } n(\%)\end{array}$ & $\begin{array}{c}5 \\
(50)\end{array}$ & $6(50)$ & $\begin{array}{c}6 \\
(54.5)\end{array}$ & $\begin{array}{c}17 \\
(51.5)\end{array}$ & $\begin{array}{c}1 \\
(9.1)\end{array}$ & $3(30)$ & $0(0)$ & $4(2.9)$ & $\begin{array}{c}21 \\
(32.8)\end{array}$ \\
\hline $\begin{array}{l}\text { Placement of students who did not } \\
\text { participate in research, } n(\%)\end{array}$ & NR & $3(50)$ & $\begin{array}{c}6 \\
(100)\end{array}$ & 9 (NA) & $\begin{array}{c}1 \\
(100)\end{array}$ & $\begin{array}{c}2 \\
(66.7)\end{array}$ & NA & $3(75)$ & (NA) \\
\hline $\begin{array}{r}\text { Students who pursued training, } \\
\text { n (\%) }\end{array}$ & $0(0)$ & $\begin{array}{c}2 \\
(33.3)\end{array}$ & $\begin{array}{c}1 \\
(16.7)\end{array}$ & $\begin{array}{c}3 \\
(17.6)\end{array}$ & $\begin{array}{c}1 \\
(100)\end{array}$ & $\begin{array}{c}2 \\
(66.7)\end{array}$ & NA & $3(75)$ & $\begin{array}{c}6 \\
(28.6)\end{array}$ \\
\hline $\begin{array}{r}\text { Students who placed into } \\
\text { training, } \mathrm{n}(\%)\end{array}$ & NA & $1(50)$ & $\begin{array}{c}1 \\
(100) \\
\end{array}$ & $\begin{array}{c}2 \\
(66.7) \\
\end{array}$ & $\begin{array}{c}1 \\
(100) \\
\end{array}$ & $1(50)$ & NA & $\begin{array}{c}2 \\
(66.7) \\
\end{array}$ & $\begin{array}{c}4 \\
(66.7) \\
\end{array}$ \\
\hline $\begin{array}{r}\text { Students who pursued a job, } n \\
(\%)\end{array}$ & NR & $\begin{array}{c}4 \\
(66.7)\end{array}$ & $\begin{array}{c}5 \\
(83.3)\end{array}$ & 9 (NA) & $0(0)$ & $\begin{array}{c}1 \\
(33.3)\end{array}$ & NA & $1(25)$ & $\begin{array}{c}10 \\
(\mathrm{NA})\end{array}$ \\
\hline Students who placed into a job, n (\%) & NR & $2(50)$ & $\begin{array}{c}5 \\
(100)\end{array}$ & 7 (NA) & NA & $\begin{array}{c}1 \\
(100)\end{array}$ & NA & $\begin{array}{c}1 \\
(100)\end{array}$ & $\begin{array}{c}8 \\
\text { (NA) }\end{array}$ \\
\hline
\end{tabular}

Training, residency or fellowship; NR, not reported in 2015; NA, not applicable (2015 missing data or 2020 all students participated in research) 
Figure 1. Timeline of process to support fourth-year student pharmacist research

Previous process (2015-2017)

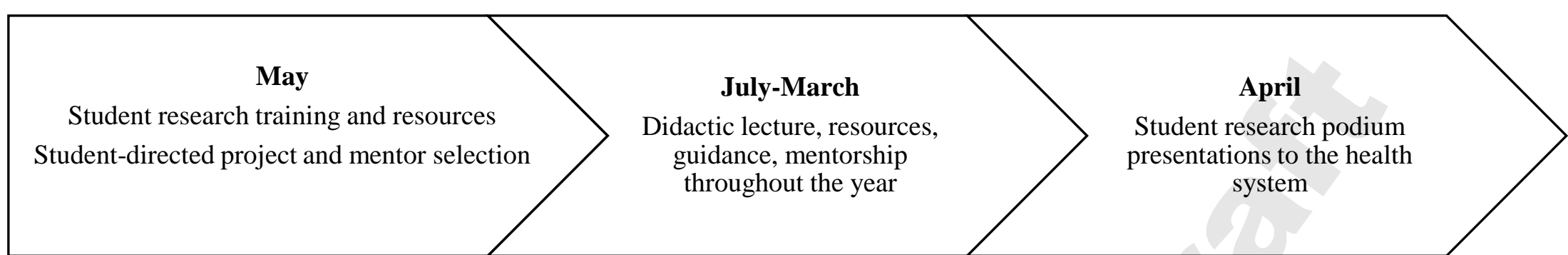

New process (2018-2020)

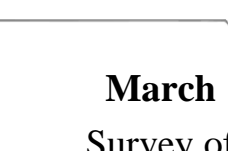

Survey of preceptors for student research project opportunities

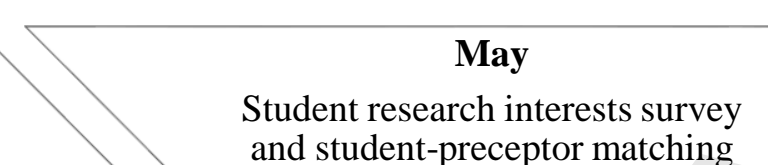
and student-preceptor matching Student research training

Scholarship expectations agreement signed by students and mentors

\section{July-November}

Poster workshop and other education

Poster and platform opportunities announced
December-April

Manuscript

workshop

Student podium presentation to the health system 